\title{
HUBUNGAN NYERI KEPALA DENGAN GANGGUAN TIDUR PADA LANSIA DI PANTI SOSIAL TRESNA WERDHA BUDI SEJAHTERA BANJARBARU TAHUN 2014
}

\author{
Rusmilawaty $^{1}$, Darmayanti ${ }^{2}$
}

\begin{abstract}
ABSTRAK
Lansia yang mengalami nyeri kepala sering merasakan ketidaknyamanan dan menganggu kuantitas dan kualitas tidur sehingga mempengaruhi kesehatan lansia. Studi pendahuluan terhadap10 orang lansia di Panti Sosial Tresna Werda Budi Sejahtera Banjarbaru didapatkan 6 orang mengalami gangguan tidur karena nyeri kepala, 2 orang kadang-kadang terbangun tengah malam dan 2 orang tidak mengalami gangguan tidur. Penelitian bertujuan untuk menganalisa hubungan nyeri kepala dengan gangguan tidur pada lansia di panti sosial Tresna Werda Budi Sejahtera Banjarbaru. Desain penelitian menggunakan survey analitik dengan pendekatan cross sectional. Populasi penelitian berjumlah 110 orang. Sampel Berjumlah 65 orang. Analisis data menggunakan uji Spearman Rank. Hasil penelitian menunjukkan bahwa tingkat nyeri kepala sebagian besar pada kategori sedang sebanyak 25 orang $(38,4 \%)$, responden yang mengalami gangguan tidur 53 orang $(81,5 \%)$ dan ada hubungan nyeri kepala dengan gangguan tidur pada lansia di panti sosial Tresna Werdha Budi Sejahtera Banjarbaru. Bagi petugas kesehatan di Panti Werdha agar memberikan informasi cara mengatasi gangguan tidur sehingga dapat meningkatkan kualitas kehidupan lansia. Bagi peneliti selanjutnya dapat meneliti faktor-faktor lain seperti pola hidup dan kecemasan.
\end{abstract}

Kata Kunci: Nyeri kepala, Gangguan tidur, lansia

\begin{abstract}
The old people who get headache often feeling uncomfortable, their quantity and quality of sleep also disturbed. Absolutely It will affect their health. The earlier study to 10 olderly in social home Tresna Werdha Budi Sejahtera Banjarbaru has gotten 6 people had sleep disorder causing by headache, 2 people woke up at the midnight sometimes, and 2 people didn't have sleep disorder. The purpose of this to analyze the corelation of headache with sleep disorder on elderly in social home tresna werdha budi sejahtera at Banjarbaru. The kind of the research is using the analytic survey by cross sectional approach. The research population amount are 110 people. The amount of the samples are 65 people. Data analysis is using analytic survey by cross sectional approach. The research population amount are 110 people. The amount of the samples are 65 people. The result of the researh shown that headache in middle level has 25 sufferer (38,4\%), sleep disorder respondents 53 people (81,5\%), then there are a corelation of headache with sleep disorder in social home Tresna Werdha Budi Sejahtera Banjarbaru. To health workers at werdha home be expected to giving the information of how to overcome the sleep disorder so that will increase the quality of olderly life. And for the next researcher will able to research the other factors as the fearnes and lifestyle.
\end{abstract}

Key word: headache, sleep disorder, olderly 


\section{PENDAHULUAN}

Lanjut usia (lansia) adalah bagian dari proses tumbuh kembang. Manusia tidak secara tiba-tiba menjadi tua, tetapi berkembang dari bayi, anak-anak, dewasa dan akhirnya menjadi tua. Lansia merupakan suatu proses alami yang ditentukan oleh Tuhan Yang Maha Esa. Semua orang akan mengalami proses menjadi tua dan masa tua merupakan masa hidup manusia yang terakhir (Azizah, 2011).

Manusia yang berumur 60 tahun ke atas dikatakan sebagai lansia. Lansia mengalami perubahan atau kemunduran dalam berbagai aspek kehidupannya, baik secara fisik maupun psikis. Perubahan kondisi fisik meliputi perubahan dari tingkat sel sampai ke semua sistem organ tubuh, muskloskletal, gastrointestinal, urogenital, endokrin dan integumen (Mubarak,2009).

Menurut organisasi kesehatan dunia (WHO) saat ini di seluruh dunia, jumlah lansia diperkirakan lebih dari 629 juta jiwa (1 dari 10 orang berusia lebih dari 60 tahun), dan pada tahun 2025, lanjut usia akan mencapai 1,2 milyar. Secara demografis, pada tahun 2005-2010 jumlah lansia akan sama dengan jumlah anak balita, yaitu sekitar 19,3 juta jiwa (9\%) dari jumlah penduduk. Bahkan pada tahun 2020-2025, Indonesia akan menduduki peringkat 4 negara dengan struktur dan jumlah penduduk lansia setelah RRC, India, dan Amerika Serikat dengan umur harapan hidup diatas 70 tahun (Nugroho, 2012).

Badan Pusat Statistik (BPS) jumlah lansia yang terus meningkat dari tahun ke tahun. Pada tahun 2025 jumlah lansia di Indonesia diperkirakan meningkat 4 kali lipat. Badan Pusat Statistik (BPS) melakukan survei bahwa jumlah lansia pada tahun 2006 di Indonesia sebanyak 17.717.800 jiwa atau 7,90 \% dan jumlah pada tahun 2010 sebesar 23.992.552 atau $9,77 \%$ dan pada tahun 2020 diperkirakan sebesar 28.822.879 atau 11,34\%.

Provinsi Kalimantan Selatan tahun 2009 menerbitkan angka pertumbuhan lansia yang berusia antara 45-49 tahun sebanyak 402.364 orang yang berusia antara 50-54 tahun sebanyak 346.752 orang, yang berusia antara 55-59 tahun sebanyak 218.254 orang dan yang berusia antara 60-64 tahun sebanyak 170.414 orang sedangkan yang berusia lebih dari 65 tahun sebanyak 267.302 orang. Jadi jumlah lanjut usia di Kalimantan Selatan pada tahun 2009 sebanyak 1.405.086 orang.

Masalah fisik sehari-hari yang sering di temukan pada lansia antara lain mudah lelah, kekacauan mental akut, nyeri dada, berdebar-debar, sesak nafas pada saat melakukan aktifitas/ kerja fisik, nyeri pinggang/punggung, nyeri sendi pinggul, sulit tidur, sering pusing, berat badan menurun, gangguan pada fungsi penglihatan, pendengaran, dan sulit menahan kencing (Mubarak,2009).

Nyeri kepala adalah suatu istilah sinonim yang paling tepat bagi istilah kedokteran sefalgia, dimana pada istilah orang awam sering disebut sebagai istilah sakit kepala, pening kepala dan lain-lain. Rasa nyeri atau rasa tidak mengenakan pada seluruh daerah kepala dengan batas bawah dari dagu sampai ke daerah belakang kepala (area oksipital dan sebagaian daerah tengkuk (Sjahrir,2008). Nyeri merupakan pengalaman sensorial dan emosional yang tidak menyenangkan akibat pada kerusakan jaringan yang aktual atau potensial. Stimulus nyeri ditransmisikan ke medulla spinalis, thalamus dan otak tengah. Dari thalamus serabut mentransmisikan pesan nyeri ke berbagai area di otak termasuk ke korteks sensori, korteks asosiasi, dan sistem limbik yang akan mempengaruhi tidur (Hidayat,2007).

Kebutuhan tidur merupakan kebutuhan dasar manusia yang harus dipenuhi, seiring bertambahnya usia, kebutuhan waktu tidur akan berkurang. Kebutuhan waktu tidur pada lansia yang harus dipenuhi diperkirakan 5-8 jam setiap 24 jam. Proses psikologik terkait usia dapat menyebabkan perubahan pola tidur menyerang 50\% orang yang berusia 65 tahun atau lebih yang tinggal di rumah dan $66 \%$ di fasilitas perawatan jangka panjang 
gangguan tidur mempengaruhi kualitas hidup dan berhubungan dengan angka mortalita yang lebih tinggi.

Gangguan tidur dapat disebabkan oleh dua faktor, yaitu faktor ekstrinsik misalnya lingkungan yang kurang tenang dan faktor intrinsik baik organik (nyeri, gatalgatal, kram betis, sakit gigi, dan penyakit tertentu yang membuat gelisah) atau psikogenik (depresi, kecemasan, stress, iritabilitas, dan marah yang tidak tersalurkan). Gangguan tidur juga sebenarnya bukanlah suatu penyakit melainkan gejala dari berbagai ganggun fisik, mental dan spritual. Gangguan tidur terdiri atas imsomnia, hypersomnia, parasomnia, enuresa, apnea tidur, narcolepsi, mengigau dan gangguan pola tidur (Widuri, 2010).

Di Panti Sosial Tresna Werdha Budi Sejahtera Banjarbaru Provinsi Kalimantan Selatan sebanyak 110 orang, yang terdiri dari 63 perempuan dan 47 laki-laki, lanjut usia yang berumur 60-74 tahun didapatkan jumlah lanjut usia laki-laki 26 orang $(34,2 \%)$ dan perempuan 25 orang $(32,8 \%)$ sedangkan lanjut usia tua yang berumur 75 90 tahun didapatkan jumlah lanjut usia tua laki-laki 12 orang $(15,7 \%)$ dan perempuan 13 orang $(17,1 \%)$.

Prevalensi gangguan tidur pada lansia di Amerika adalah $36 \%$ pada laki-laki dan $54 \%$ pada wanita. Hanya $26 \%$ laki-laki

\section{METODE PENELITIAN}

Rancangan penelitian ini adalah survey analitik dengan pendekatan Cross Sectional yaitu mencoba menganalisis hubungan nyeri kepala dengan gangguan tidur pada lansia di Panti Sosial Tresna Werdha Budi Sejahtera Banjarbaru Kalimantan Selatan tahun 2014. Populasi dalam penelitian ini berjumlah 110 orang lansia. Pengambilan sampel menggunakan kriteria inklusi dan kriteria eksklusi yaitu: kriteria inklusi meliputi mampu berkomunikasi dengan baik dan bersedia menjadi responden; kriteria eksklusi meliputi dimensia dan lansia di ruang isolasi. Sampel penelitian ini sebanyak 65 orang dan $21 \%$ wanita lansia yang mengatakan tidak mengalami kesulitan tidur. Penelitian menunjukkan penyebab gangguan tidur pada lansia merupakan banyak faktor, baik fisik, psikologis, pengaruh obat-obatan, kebiasaan tidur (Boedhi-Darmojo, 2009).

Hasil penelitian Dement et al, melaporkan bahwa efisiensi tidur lansia $67 \%-70 \%$. Sedangkan Luce dan Segal mengungkapkan bahwa pada kelompok lansia (40 tahun) hanya dijumpai $7 \%$ yang mengeluhkan masalah tidur (hanya dapat tidur tidak lebih dari lima jam sehari), 22\% pada usia 70 tahun (terbangun lebih awal dari pukul 05.00 pagi) dan 30\% kelompok usia 70 tahun yang banyak terbangun diwaktu malam hari (Carpenito, 2000).

Hasil penelitian Alawiyah (2013) didapat bahwa dari 23 orang lansia di Panti Sosial Tresna Werdha Budi Sejahtera Provinsi Kalimantan Selatan di Banjarbaru yang menjadi responden, hampir seluruh responden mengalami gangguan tidur yaitu sebanyak 21 orang.

Berdasarkan studi pendahuluan yang dilakukan di Panti Sosial Tresna Werdha Budi Sejahtera Banjarbaru pada tanggal 22 September 2014, pada 10 orang lansia ternyata ada 6 orang yang mengalami gangguan tidur karena nyeri kepala, 2 orang kadang - kadang dan 2 orang tidak mengalami gangguan tidur dan tidak nyeri kepala.

orang lansia di Panti Sosial Tresna Werdha Budi Sejahtera Banjarbaru Kalimantan Selatan tahun 2014.

Instrumen penelitian untuk mengukur nyeri kepala menggunakan check list dengan menilai derajat keparahan nyeri kepala menurut IHSD. Instrumen penelitian untuk mengukur gangguan tidur berupa kuesioner berjumlah 13 buah dengan alternatif jawaban ya dan tidak. Pengumpulan data dimulai dengan melakukan pendekatan terlebih dahulu dan meminta kesedian responden yang dengan dibantu oleh petugas panti kemudian melakukan wawancara terstruktur dan 
observasi dengan memperhatikan mimik wajah respoden secara langsung. Pengolahan data meliputi Editing, Scoring, Coding dan Entri data.

Analisa Univariat mengggambarkan data distribusi frekuensi variabel nyeri kepala dan gangguan tidur. Analisa Bivariat menggambarkan hubungan antara variabel independen (nyeri kepala) dengan variabel dependen (gangguan tidur) menggunakan uji statistik Spearman Rank (Rho) a 0,05 dengan tingkat kepercayaan 95\%. Pedoman untuk interpretasi koefesien korelasi atau tingkat hubungan adalah sangat rendah $(0,00-0,199)$, rendah $(0,20-0,399)$, sedang $(0,40-0,599)$, kuat $(0,60-0,799)$, dan sangat kuat $(0,80-1,000)$ (Sugiyono, 2008).

\section{HASIL PENELITIAN}

\section{Jenis Kelamin Lansia}

Tabel 1. Distribusi Frekuensi Lansia Berdasarkan Jenis Kelamin

\begin{tabular}{cccc}
\hline No & Jenis Kelamin & Frekuensi & Persen \\
\hline 1 & Laki-laki & 20 & 30,8 \\
\hline 2 & Perempuan & 45 & 69,2 \\
\hline & Jumlah & 65 & 100,0 \\
\hline
\end{tabular}

Tabel 1. menunjukkan bahwa sebagian besar responden adalah perempuan yaitu sebanyak 45 orang $(69,2 \%)$.

\section{Usia}

Tabel 2. Distribusi Frekuensi Lansia Berdasarkan usia

\begin{tabular}{cccc}
\hline No & Usia & Frekuensi & Persen \\
\hline 1 & $60-70$ & 25 & 38,4 \\
\hline 2 & $>70$ & 40 & 61,6 \\
\hline & Jumlah & 65 & 100,0
\end{tabular}

Tabel 2. menunjukkan bahwa sebagian besar responden berusia $>70$ tahun yaitu sebanyak 40 orang $(61,6 \%)$.

\section{Nyeri Kepala berdaskan jenis kelamin}

Tabel 3. Distribusi Frekuensi Nyeri Kepala berdasarkan jenis kelamin

\begin{tabular}{|c|c|c|c|c|c|c|c|}
\hline \multirow{3}{*}{ No. } & \multirow{3}{*}{ Nyeri Kepala } & \multicolumn{4}{|c|}{ Jenis Kelamin } & \multirow{3}{*}{ Total } & \multirow{3}{*}{$\%$} \\
\hline & & \multicolumn{2}{|c|}{ Laki-laki } & \multicolumn{2}{|c|}{ Perempuan } & & \\
\hline & & f & $\%$ & $f$ & $\%$ & & \\
\hline 1. & Tidak nyeri kepala & 3 & 4,6 & 4 & 6,1 & 7 & 10,8 \\
\hline 2. & Nyeri kepala ringan & 7 & 10,7 & 14 & 21,5 & 21 & 32,3 \\
\hline 3. & Nyeri kepala Sedang & 6 & 9,2 & 19 & 29,2 & 25 & 38,5 \\
\hline \multirow[t]{2}{*}{4.} & Nyeri kepala Berat & 4 & 6,15 & 8 & 12,3 & 12 & 18,4 \\
\hline & Jumlah & 20 & 30,8 & 45 & 69,2 & 65 & 100,0 \\
\hline
\end{tabular}

Tabel 3 menunjukkan bahwa sebagian besar responden yang mengalami nyeri kepala adalah perempuan, nyeri kepala ringan 14 orang $(21,5)$, nyeri kepala sedang 19 orang $(29,2)$ dan 8 orang nyeri kepala berat. 


\section{Gangguan tidur bersadarkan jenis kelamin}

Tabel 4. Distribusi Frekuensi Gangguan Tidur berdasarkan jenis kelamin

\begin{tabular}{|c|c|c|c|c|c|c|c|}
\hline \multirow{3}{*}{ No. } & \multirow{3}{*}{ Jenis Kelamin } & \multicolumn{4}{|c|}{ Gangguan Tidur } & \multirow{3}{*}{ Total } & \multirow{3}{*}{$\%$} \\
\hline & & \multicolumn{2}{|c|}{ Ya } & \multicolumn{2}{|c|}{ Tidak } & & \\
\hline & & $f$ & $\%$ & $f$ & $\%$ & & \\
\hline 1. & Laki-laki & 16 & 24,6 & 4 & 6,1 & 20 & 30,7 \\
\hline 2. & Perempuan & 37 & 56,9 & 8 & 12,3 & 45 & 69,2 \\
\hline & Jumlah & 53 & 2,5 & 12 & 97,5 & 65 & 100,0 \\
\hline
\end{tabular}

Tabel 4. menunjukkan bahwa dari 45 lansia perempuan sebanyak 37 orang $(56,9 \%)$ mengalami gangguan tidur.

\section{Analisa Univariat}

1. Nyeri Kepala

Tabel 5. Distribusi Frekuensi Lansia Berdasarkan Nyeri Kepala

\begin{tabular}{cccc}
\hline No. & Nyeri Kepala & Frekuensi & Persen \\
\hline 1. & Tidak Nyeri & 7 & 10,8 \\
\hline 2. & Nyeri Kepala Ringan & 21 & 32,3 \\
\hline 3. & Nyeri Kepala Sedang & 25 & 38,4 \\
\hline 4. & Nyeri Kepala Berat & 12 & 18,5 \\
\hline & Jumlah & 65 & 100,0 \\
\hline
\end{tabular}

Tabel 5 menunjukkan bahwa sebagian besar responden mengalami nyeri kepala sedang berjumlah 25 orang $(38,4 \%)$.

\section{Gangguan Tidur}

Tabel 6. Distribusi Frekuensi Lansia Berdasarkan Gangguan Tidur

\begin{tabular}{cccc}
\hline No. & Gangguan Tidur & Frekuensi & Persen \\
\hline 1. & $\mathrm{Ya}$ & 53 & 81,5 \\
\hline 2. & Tidak & 12 & 18,5 \\
\hline & Jumlah & 65 & 100,0
\end{tabular}

Tabel 6. menunjukkan bahwa sebagian besar responden mengalami gangguan tidur berjumlah 53 orang $(81,5 \%)$.

\section{Analisa Bivariat}

Tabel 7. menunjukkan dari 12 responden yang mengalami nyeri kepala berat 12 responden (100\%) mengalami gangguan tidur, 25 responden yang mengalami nyeri kepala sedang 23 responden $(92,0 \%)$ mengalami gangguan tidur, 21 responden yang mengalami nyeri kepala ringan 16 responden (76,2\%) mengalami gangguan tidur dan 7 responden yang tidak mengalami nyeri kepala 2 responden $(28,6 \%)$ mengalami gangguan tidur. Hasil uji Spearman Rank (Rho) didapatkan $p<\alpha$ artinya ada hubungan nyeri kepala dengan gangguan tidur pada lansia di Panti Sosial Tresna Werdha Budi Sejahtera Banjarbaru Tahun 2014 dengan tingkat kepercayaan korelasi sedang. 
Tabel 7. Hubungan Nyeri Kepala dengan Gangguan Tidur

\begin{tabular}{|c|c|c|c|c|c|c|c|}
\hline \multirow{3}{*}{$\begin{array}{l}\mathbf{N} \\
\text { o. }\end{array}$} & \multirow{3}{*}{ Nyeri Kepala } & \multicolumn{4}{|c|}{ Gangguan Tidur } & \multirow{3}{*}{ Total } & \multirow{3}{*}{$\%$} \\
\hline & & \multicolumn{2}{|c|}{ Ya } & \multicolumn{2}{|c|}{ Tidak } & & \\
\hline & & $f$ & $\%$ & $f$ & $\%$ & & \\
\hline 1. & Tidak Nyeri & 2 & 28,6 & 5 & 71,4 & 7 & 100 \\
\hline 2. & Nyeri Kepala Ringan & 16 & 76,2 & 5 & 23,8 & 21 & 100 \\
\hline 3. & Nyeri Kepala Sedang & 23 & 92,0 & 2 & 8,0 & 25 & 100 \\
\hline \multirow[t]{2}{*}{4.} & Nyeri Kepala Berat & 12 & 100,0 & 0 & 0 & 12 & 100 \\
\hline & Jumlah & 53 & 81,5 & 12 & 12,0 & 65 & 100 \\
\hline
\end{tabular}

Uji spearman rank $\rho, 001$, korelasi tingkat hubungan sedang

\section{PEMBAHASAN}

\section{Nyeri Kepala}

Hasil penelitian didapatkan sebagian besar responden mengalami nyeri kepala sedang. Nyeri kepala adalah suatu istilah sinonim yang paling tepat bagi istilah kedokteran sefalgia, pening kepala dan sebagainya. Rasa nyeri atau tidak mengenakkan pada seluruh daerah kepala dengan batas bawah dari dagu sampai ke daerah belakang kepala (area oksipital dan sebagian daerah tengkuk) (Sjahrir,2008). Nyeri kepala ialah rasa nyeri atau rasa tidak nyaman di bagian atas (superior) kepala yang kadang dapat menyebar ke wajah, gigi, rahang, kuduk dan leher (Lumbatobing,2008).

Nyeri kepala pada lansia ini dialami karena adanya faktor pencetus seperti stres karena keluarga jarang mengunjungi, telat makan dan kurangnya istirahat, nyeri leher dan sering melakukan aktivitas berat atau melelahkan.

Lumbatobing (2008) menjelaskan bahwa nyeri kepala lebih banyak dialami dan lebih cepat dirasakan oleh perempuan dari pada laki-laki dengan perbandingan 5:4. Pada penelitian ini nyeri kepala lebih banyak dialami oleh lansia perempuan.

\section{Gangguan Tidur}

Hasil penelitian didapatkan bahwa sebagian besar responden mengalami gangguan tidur. Menurut Prasadja (2009) Pola tidur seseorang pasti mengalami perubahan seiring dengan bertambah usia yang semakin beragamnya pekerjaan atau aktivitas. Semakin bertambah usia, efisiensi tidur diartikan sebagai jumlah waktu tidur berbanding dengan waktu berbaring di tempat tidur. Kebutuhan tidur pun semakin menurun. Hal ini dialami oleh lansia. Lansia wanita lebih banyak mengalami insomnia, dibandingkan dengan lansia pria yang lebih banyak menderita sleep apnea atau kondisi medis lain yang dapat menggangu tidur.

Gangguan tidur yang dialami lansia di Panti Sosial Tresna Werdha Budi Sejahtera Banjarbaru antara lain jumlah jam tidur yang kurang dari 5 jam, sulit untuk memulai tidur, sering terbangun pada malam hari, terbangun pada malam hari karena merasa nyeri, gelisah saat tidur, merasa lelah, lemas, dan lesu saat bangun tidur, sakit kepala saat bangun tidur, sering mengantuk di siang hari, tidak tidur cukup di siang hari, dan marah-marah setelah bangun tidur.

Widuri (2010) menyatakan bahwa gangguan tidur pada lansia adalah sebuah hal yang sering di alami oleh kelompok lansia. Gangguan tidur ini dapat disebabkan oleh dua faktor, yaitu faktor ekstrinsik (luar) misalnya lingkungan yang kurang tenang dan faktor intrinsik (dalam) baik organik (nyeri, gatal-gatal, kram betis, sakit gigi, dan penyakit tertentu yang membuat gelisah) atau psikogenik (depresi, kecemasan, stress, iritabilitas, dan marah yang tidak tersalurkan).

\section{Hubungan Nyeri Kepala dengan Gangguan Tidur}

Hasil Penelitian didapatkan ada hubungan yang bermakna antara nyeri kepala dan gangguan tidur di Panti Sosial 
Tresna Werdha Budi Sejahtera Banjarbaru. Gangguan tidur sering dialami oleh lansia di sebabkan oleh banyak faktor yaitu faktor fisik, psikologis maupun mental (Widuri, 2010). Gangguan tidur pada lansia bisa berupa gangguan kesulitan tidur ataupun gangguan mempertahankan waktu tidur nyenyak. Nyeri kepala secara langsung dapat mempengaruhi tidur lansia. rasa tidak nyaman pada seluruh area kepala degan

\section{KESIMPULAN}

Sebagian

besar responden mengalami nyeri kepala sedang sebesar $38,4 \%$, hampir seluruh responden mengalami gangguan tidur yaitu sebesar $81,5 \%$ dan ada hubungan nyeri kepala dengan gangguan tidur pada lansia di Panti Sosial Tresna Werda Budi Sejahtera Banjarbaru

Penelitian ini berguna sebagai upaya pencegahan terjadinya gangguan tidur pada lansia di Panti Sosial Tresna Werdha Budi

\section{DAFTAR RUJUKAN}

Alawiyah, 2013. Hubungan rematik dengan gangguan tidur pada lansia di PSTW Budi Sejahtera Banjarbaru. Skripsi. STIKes Muhammadiyah Banjarmasin.

Azizah, 2001. Keperawatan lanjut usia. Yogyakarta: Graha IImu.

Darmojo . 2009. Buku ajar geriatri (Ilmu Kesehatan Usia Lanjut). Jakarta: FKUI.

Hidayat, 2007. Metode penelitian keperawatan dan teknik analisis data. Jakarta: Salemba Medika.

Lumbantobing, 2008. Nyeri kepala nyeri punggung bawah nyeri kuduk : Jakarta FKUI.

Mubarak, dkk . 2008. Kebutuhan dasar manusia. Jakarta. EGC.

Nugroho, Wahjudi, 2008. Keperawatan gerontik dan geriatrik. Edisi 3 . Jakarta: EGC.

Prasadja, 2009. Ayo bangun dengan bugar karena tidur yang benar. Jakarta: Mizan Publika. batas bawah dari dagu sampai ke daerah belakang kepala yang membuat lansia mengalami tidur yang tidak adekuat baik kuantitas maupun kualitasnya. Lansia yang mengalami gangguan tidur dan mengalami nyeri kepala disebabkan oleh faktor lingkungan seperti suara televisi dan radio yang terlalu keras dan suhu kamar yang panas.

Sejahtera Banjarbaru yang di akibatkan karena nyeri kepala. Bagi petugas kesehatan diharapkan dapat memberikan penyuluhan terhadap lansia cara mengatasi nyeri kepala dan gangguan tidur yaitu dengan berolah raga ringan dan teratur seperti jalan kaki pagi hari, berlari-lari kecil, senam, atau sekedar peregangan otot. Bagi peneliti selanjutnya dapat meneliti faktorfaktor lain seperti pola hidup dan kecemasan

Sjahrir. 2008 . Nyeri kepala \& vertigo. Cetakan pertama. Jakarta: Pustaka Cendikia press.

Sugiyono . 2010. Statistik untuk penelitian. Cetakan ke 16. Bandung: Penerbit Alfabeta.

Widuri. 2010. Asuhan keperawatan pada lanjut usia di tatanan klinik. Yogyakarta: Fitramaya. 